\title{
Thermal comfort properties of cotton/spandex single jersey knitted fabric
}

\author{
DOI: 10.35530/IT.072.03.1760
}

AMANY KHALIL

ABDELHAMID R.R ABOALASAAD

PAVLA TĚŠINOVÁ

\section{ABSTRACT - REZUMAT \\ Thermal comfort properties of cotton/spandex single jersey knitted fabric}

Knitted fabrics are characterized by comfort compared to woven fabrics due to their high extensibility and air permeability, but they have lower dimensional stability after repeated washing especially single jersey knitted fabric (SJKF). Therefore, the spandex (Lycra) core-spun yarns are used to maintain the dimensions of knitted fabrics during use and after repeated stresses. In this study, nine elastic SJKF samples were produced at three levels of loop length and spandex percent using yarn linear density 30/1 Ne. For comparison, three $100 \%$ cotton knitted samples were produced with the same levels of loop length and yarn count. The dimensional and thermal comfort properties of the long-stretch samples were compared with the short-stretch cotton knitted fabric. The thermal comfort properties (thermal conductivity, resistance, absorptivity, and water vapour permeability), air permeability, and dimensional properties were measured and compared to $100 \%$ cotton samples. The results showed that the stitch density, fabric density, fabric thickness, and thermal resistance increased, whereas the air, water vapour permeability, and spirality angle decreased in cotton/spandex samples.

Keywords: thermal comfort properties, spandex, stretchable knitted fabrics, core-spun yarn, spirality angle, thickness

Proprietățile de confort termic ale tricoturilor glat din bumbac/spandex

Tricoturile prezintă proprități de confort comparabile cu cele ale țesăturilor, datorită extensibilității ridicate și permeabilității la aer, dar au stabilitate dimensională mai mică după spălarea repetată, în special tricotul glat (SJKF). Prin urmare, firele filate cu miez de spandex (Lycra) sunt utilizate pentru a menține dimensiunile tricoturilor în timpul utilizării și după solicitări repetate. În acest studiu, au fost realizate nouă probe elastice SJKF și trei probe 100\% bumbac tricotate la trei niveluri de lungime buclă și procent de spandex, folosind densitatea liniară a firului de 30/1 Ne. Pentru comparație, au fost realizate trei probe tricotate din $100 \%$ bumbac cu aceleași niveluri de lungime a buclei și densitate liniară. Proprietățile de confort dimensional și termic ale probelor cu întindere ridicată au fost comparate cu tricotul din bumbac cu întindere redusă. Proprietățile de confort termic (conductivitatea termică, rezistența termică, capacitatea de absorbție și permeabilitatea la vapori de apă), permeabilitatea la aer și proprietățile dimensionale au fost măsurate și comparate cu probe din 100\% bumbac. Rezultatele au arătat că desimea ochiurilor, grosimea materialului textil și rezistența termică au crescut, în timp ce permeabilitatea la aer și la vapori de apă, precum și unghiul de spirală au scăzut în probele din bumbac/spandex.

Cuvinte-cheie: proprietăți de confort termic, spandex, tricoturi elastice, fire filate cu miez, unghi de spirală, grosime

\section{INTRODUCTION}

Single jersey knitted fabrics (SJKF) are used for under- and outer-wear compared to woven fabrics because of their high extensibility (compression and elongation of individual stitch). If these fabrics were produced from $100 \%$ cotton yarns, they don't have the ability to recover the stitch rearrangement [1]. To enhance the recovery and dimensional stability of knitted fabric, the spandex yarns are incorporated with cotton yarns in weft circular machine. Spandex is used as a core in the core spun yarns with natural and synthetic fibres or additional yarn (full and half plated) in circular knitting machines. Spandex improves the dimensional stability, body fit of weft knitted fabric and freedom of body movements but it also has a negative effect on other important properties such as air permeability and thermal comfort properties. Thermal comfort is one of the most important parameter of clothing comfort. Thermal comfort is defined as a state of satisfaction with the thermal conditions of the environment. Most of studies focused only on either dry or wet state [2-4]. The thermal comfort properties depend on the temperature difference between environment and skin, yarns structure and material, fabric thickness, porosity, areal density, number of fabric layers, trapped air, and fabric structure [5].

There are many researchers investigated the effect of spandex on the dimensional and mechanical properties of different knitted fabric structures. The dimensional and physical properties of cotton/spandex single jersey fabrics were investigated and the results were compared with fabrics knitted from cotton alone [6]. The effect of extension increase percent of bare Lycra yarns during loop formation on the geometrical, 
physical and mechanical properties of plain jersey fabrics was investigated [1]. Half-plated, full-plated, and $100 \%$ cotton plain and rib knitted fabric structures were investigated for physical, dimensional, geometrical, and some comfort properties and compared to each other [7]. The relations between Lycra consumption and fabric dimensional and elastic behaviour were studied [8]. The influences of raw material, yarn count, pattern and elastomeric yarn ratio on the performance and physical properties of the plain, pique, double-pique, and fleecy patterned knitted fabrics were found out [9]. The dimensional and physical properties of cotton/elastane single jersey fabrics were measured and compared to $100 \%$ cotton knitted fabric [10]. Comfort properties such as stretch, recovery, air permeability, and wicking of SJKF of three different fibre contents (cotton/spandex, rayon/spandex, and polyester/spandex) were compared [11]. The effects of spandex brand, tightness factor of the base, and spandex yarn on the dimensional and physical properties of cotton/spandex single jersey fabrics were investigated [12]. The physical, dimensional, and mechanical properties of back plaited cotton/spandex SJKF were measured and compared to $100 \%$ cotton fabric [13]. Dimensional characteristics of core-spun cotton/spandex and cotton samples were studied [14]. The dimensional properties of single jersey fabric produced from Polyester/Lycra air-covered yarns with different loop lengths were tested [15]. The effect of spandex yarn input tension, yarn loop length, and spandex yarn linear density on the elastic properties of stretchable knitted fabrics were studied [16].

Based on the previous research [1,7-16], spandex has a significant effect on the dimensional, physical, and mechanical properties of knitted fabrics. The fabric thickness, stitch density, and weight per unit area increased whereas the air permeability and spirality angle decreased. There is a limited research that studied the effect of spandex on thermal properties. The properties of the weft knitted fabrics with different structures (single jersey, rib $1 \times 1$, and full cardigan) produced from core and dual core-spun yarns at different levels of loop length were compared [17]. Results showed that the yarn type had a significant effect on fabric recovery, elasticity, and shrinkage. However, it had a nonsignificant effects on drapability, thermal resistivity, and air permeability. So, more research is required in this point.

The proposed research aims to investigate the effect of spandex rate on the dimensional and thermal comfort properties of SJKF and compare it with the properties of $100 \%$ cotton fabric without spandex.

\section{EXPERIMENTAL}

\section{Materials}

Nine elastic SJKF samples were produced on VIGNONI SJ-B at three levels of loop length and spandex percent with yarn count 30/1 Ne. For comparison, three $100 \%$ cotton fabric samples were produced at the same yarn count and levels of loop length. Circular knitting machine and samples specifications are listed in tables 1 and 2 respectively. All fabric samples were treated according to elastic knitted fabric finishing recipe. After finishing, all samples were washed three consecutive washing cycles at $40^{\circ} \mathrm{C}$ in laboratory washing machine.

Table 1

\begin{tabular}{|c|c|c|c|c|}
\hline \multicolumn{5}{|c|}{ MACHINE SPECIFICATIONS } \\
\hline $\begin{array}{c}\text { Machine } \\
\text { Type }\end{array}$ & Model & $\begin{array}{c}\text { No. of } \\
\text { feeders }\end{array}$ & $\begin{array}{c}\text { Diameter } \\
\text { (inch) }\end{array}$ & Gauge \\
\hline $\begin{array}{c}\text { Single jersey } \\
\text { (Circular) }\end{array}$ & $\begin{array}{c}\text { VIGNONI } \\
\text { SJ-B }\end{array}$ & 51 & 17 & 24 \\
\hline
\end{tabular}

Table 2

\begin{tabular}{|c|c|c|c|c|c|}
\hline \multicolumn{6}{|c|}{ SAMPLES' PRODUCTION SETTINGS } \\
\hline \multirow{2}{*}{\multicolumn{2}{|c|}{ Lycra percent $\%$}} & \multirow{2}{*}{$\begin{array}{c}\begin{array}{c}100 \% \\
\text { cotton }\end{array} \\
0 \\
\end{array}$} & \multicolumn{3}{|c|}{$\begin{array}{l}\text { Cotton/Lycra core } \\
\text { spun yarn }\end{array}$} \\
\hline & & & 5.5 & 6 & 6.5 \\
\hline \multirow{3}{*}{$\begin{array}{l}\text { Loop length } \\
\text { level }(\mathrm{mm})\end{array}$} & 2.7 & $\checkmark$ & $\checkmark$ & $\checkmark$ & $\checkmark$ \\
\hline & 2.9 & $\checkmark$ & $\checkmark$ & $\checkmark$ & $\checkmark$ \\
\hline & 3.1 & $\checkmark$ & $\checkmark$ & $\checkmark$ & $\checkmark$ \\
\hline
\end{tabular}

\section{Methods}

Fabric thickness was measured according to ASTM D1777. The spirality angle is measured as the angle between the wale line and the line parallel to the machine running direction $[6,18]$. The fabric bulk density is calculated by equation 1 [19]:

$$
\text { Bulk density }\left(\frac{\mathrm{kg}}{\mathrm{m}^{3}}\right)=\frac{W}{t}
$$

where $W$ is fabric weight per unit area $\left(\mathrm{g} / \mathrm{m}^{2}\right)$ and $t-$ fabric thickness (mm).

Thermal conductivity, resistance, and absorptivity were measured using Alambeta tester [20, 21] according to ISO 8301.

Relative water vapour permeability was tested by Permetest according to ISO 11092. Air permeability was measured according to ASTM D737. The statistical multivariate analysis of variance (MANOVA) was performed for the experimental results using SPSS program.

\section{RESULTS AND DISCUSSION}

\section{Fabric thickness}

Figure 1 shows the effect of loop length on the fabric thickness of cotton/spandex and $100 \%$ cotton plain knitted fabric at three level of spandex percent (6.5, 6 , and $5.5 \%$ ). The thickness of cotton/spandex sample is higher than $100 \%$ cotton samples by $61 \%$ at 2.7 loop length. The fabric thickness is equal to twice of yarn diameter for jamming condition $\left(t=2^{*} d\right.$ where $t$ is fabric thickness, $d$-yarn diameter, wale spacing $=4^{*} d$ and course spacing $=2 \sqrt{3}^{*} d$ ) as shown in figure 2,a. So we can interpret that because the spandex leads to stitch overlapping [1] which increases 


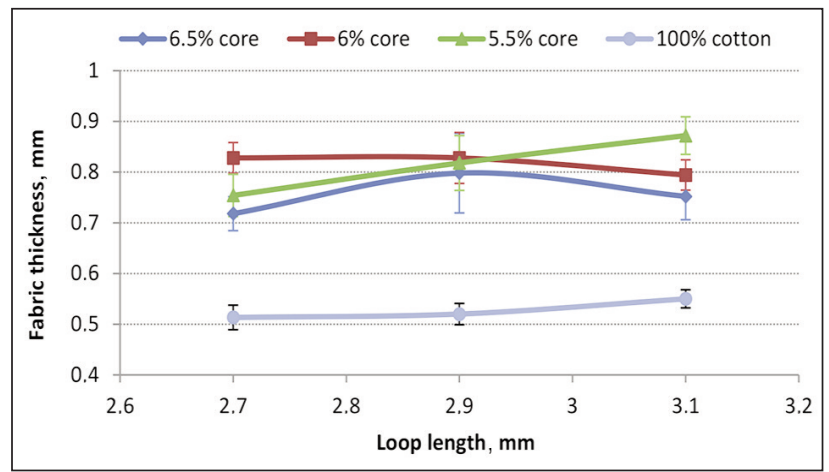

Fig. 1. Effect of loop length on the fabric thickness
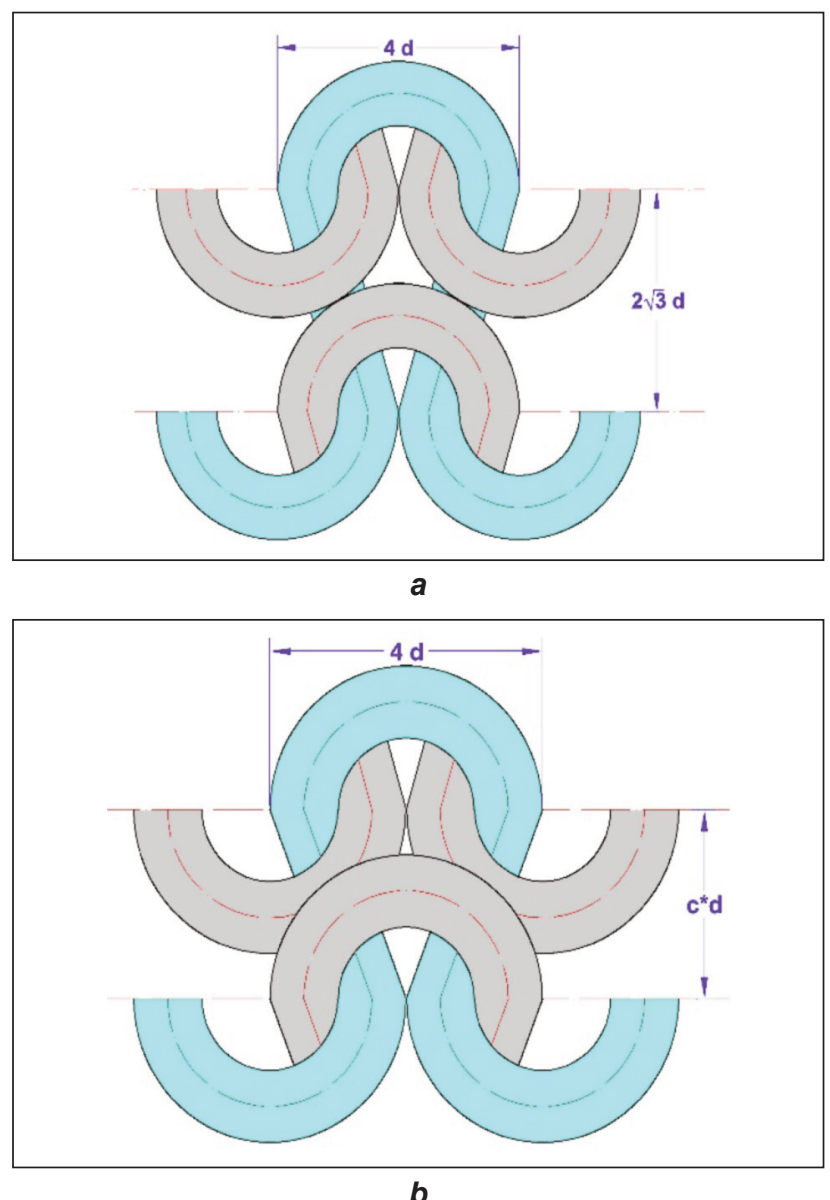

Fig. 2. Theoretical geometry of single jersey loop structure: $a$ - jamming condition; $b$ - stitch overlapping, $d$ is yarn diameter and $c<2 \sqrt{3}$

the fabric thickness, as shown in figure 2,b (course spacing $<2 \sqrt{3} * d$ ). There is a slight effect of loop length on the fabric thickness and there isn't obvious effect of spandex percent (from 5.5 to 6.5\%). Therefore, the increase of fabric thickness may lead to increase of thermal resistance.

\section{Stitch density}

The stitch density per unit area was calculated by multiplying the course per unit length by the wales per unit length. Figure 3 shows the effect of loop length on stitch density of cotton/spandex and $100 \%$ cotton samples.

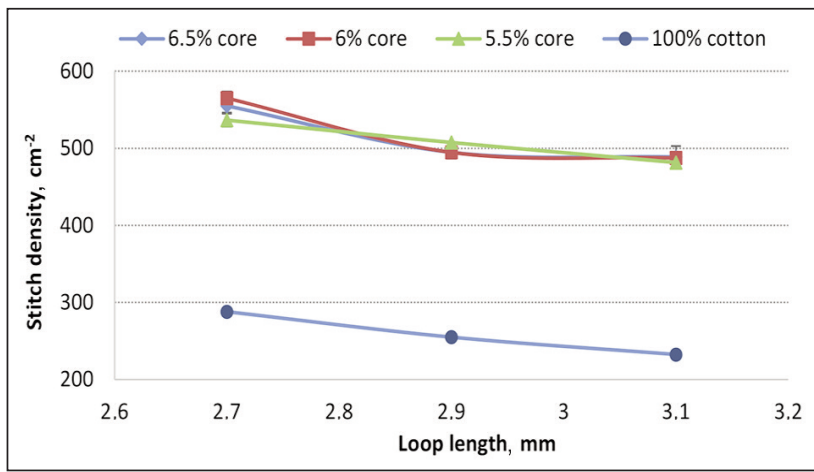

Fig. 3. Effect of loop length on the stitch density

In general, the stitch density decreases with increasing the loop length. The stitch density of elastic fabric is higher than $100 \%$ cotton fabric by $96 \%$ at loop length $2.7 \mathrm{~mm}$ because Lycra leads to convergence of wales and courses, so the fabric becomes more tight.

\section{Thermal conductivity}

The thermal conductivity of elastic knitted fabric is higher than $100 \%$ cotton by $17 \%$ and $36 \%$ at loop length $2.7,3.1 \mathrm{~mm}$ respectively and went up when the spandex percent decreased from 6.5 to $5.5 \%$, as shown in figure 4 . This may due to the increase of stitch density and fabric density which means that the amount of fibres increased and the rate of heat transfer by conduction increased as well. The statistical analysis proved that the spandex percent and loop length had a significant effect on the thermal conductivity (table 3 ).

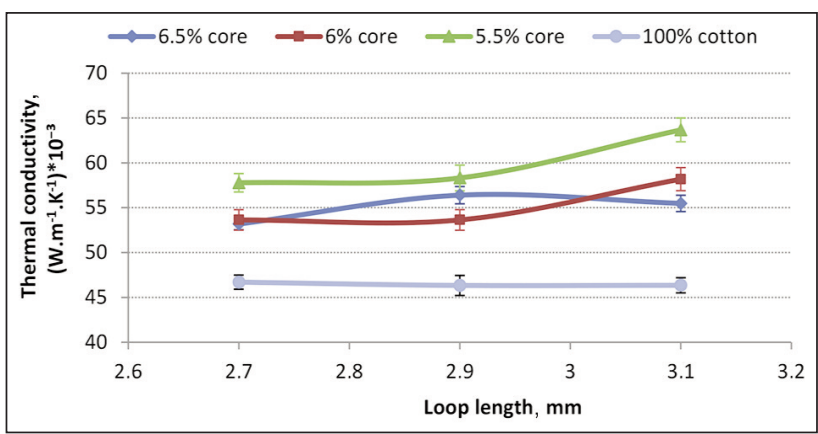

Fig. 4. Effect of loop length on the thermal conductivity

\section{Thermal resistance}

The thermal resistance of elastic plain knitted fabric increased by $47 \%$ compared to $100 \%$ cotton fabric although the cotton fabric density is lower than the elastic fabric, as shown in figure 5 . So, the pores size and its distribution play an important rule to entrap air inside the fabric. The thermal resistance increases with fabric thickness increasing according to the equation 2 [22].

$$
R=\left(\frac{t}{\lambda}\right)
$$

where $R$ is thermal resistance $\left(\mathrm{K} \cdot \mathrm{m}^{2} \cdot \mathrm{W}^{-1}\right), \lambda$ - thermal conductivity $\left(\mathrm{W} \cdot \mathrm{m}^{-1} \cdot \mathrm{K}^{-1}\right)$, and $t-$ fabric thickness $(m)$. 


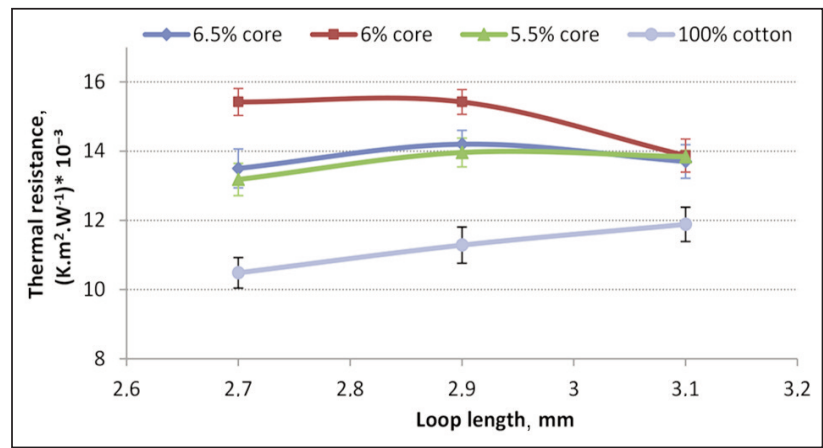

Fig. 5. Effect of loop length on the thermal resistance

So, the elastic fabric has the ability to maintain the body temperature if it is used as winter clothing. The statistical analysis showed that the spandex percent and loop length had an insignificant effect on the thermal resistance.

\section{Thermal absorptivity}

Thermal absorptivity is the objective measurement of warm cool feeling of the fabric. Fabrics with a lower thermal absorptivity value have warm feeling and vice-versa [23]. The thermal absorptivity increases with increasing the thermal conductivity and fabric density according to the following equation [21].

$$
b=(\lambda \rho c)^{1 / 2}
$$

where $b$ is thermal absorptivity $\left(\mathrm{W} \cdot \mathrm{S}^{1 / 2} \cdot \mathrm{m}^{-2} \cdot \mathrm{K}^{-1}\right)$, $\lambda$ - thermal conductivity $\left(\mathrm{W} \cdot \mathrm{m}^{-1} \cdot \mathrm{K}^{-1}\right), \rho-$ fabric density $\left(\mathrm{kg} / \mathrm{m}^{3}\right), \mathrm{c}-$ specific heat capacity $\left(\mathrm{J} \cdot \mathrm{kg}^{-1} \cdot \mathrm{K}^{-1}\right]$. Therefore, the thermal absorptivity of elastic fabric is more than $100 \%$ cotton by $29 \%$ and $53 \%$ at the loop length 2.7 and $3.1 \mathrm{~mm}$ respectively and gives a cool feeling at first touch, as shown in figure 6 . The spandex percent had a significant effect and loop length had an insignificant effect on the thermal absorptivity.

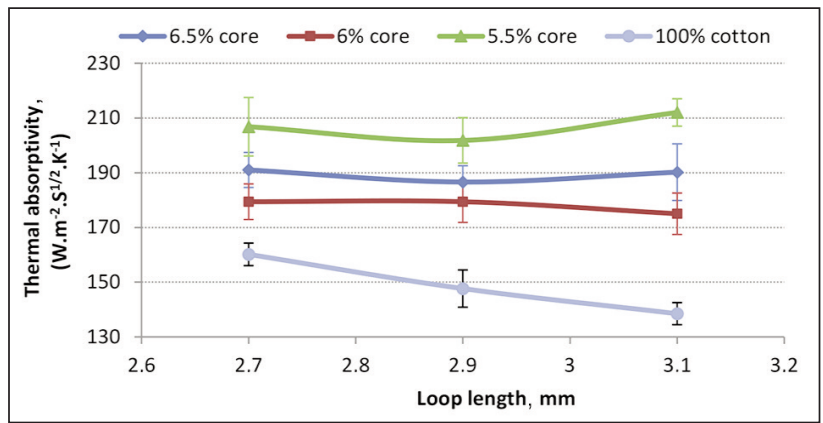

Fig. 6. Effect of loop length on the thermal absorptivity

\section{Water vapour permeability}

Figure 7 shows the relative water vapour permeability (RWVP) of elastic and $100 \%$ cotton SJKF at three levels of loop length and spandex percent. The RWVP of elastic fabric is less than $100 \%$ cotton fabric because the bulk density of $100 \%$ cotton is less than the elastic fabric. Therefore the $100 \%$ cotton fabric contain a large size of pores that can permit the water vapour transfer by convection. So, the elastic

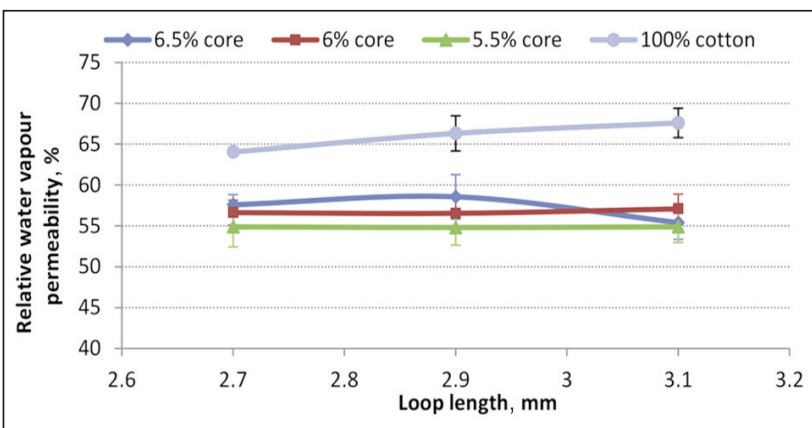

Fig. 7. Effect of loop length on the relative water vapour permeability

SJKF gives a discomfort feeling because it fails to transfer the water vapour compared to $100 \%$ cotton fabric and water vapour may convert to sweat. The RWVP slightly went up when the spandex percent increased. The spandex percent, rather than the loop length, had a significant effect on the RWVP.

\section{Air permeability}

Figure 8 displays the effect of loop length on the air permeability of SJKF at three levels of the spandex percent and loop length. In general, the air permeability increased by the increasing of loop length and the air permeability of elastic fabric is less than $100 \%$ cotton fabric by $94 \%$. This is due to increasing of stitch density as shown in figure 3 and the elastic fabric becomes much tight. The statistical analysis showed that the loop length had a significant effect whereas the spandex percent had a nonsignificant effect on the air permeability.

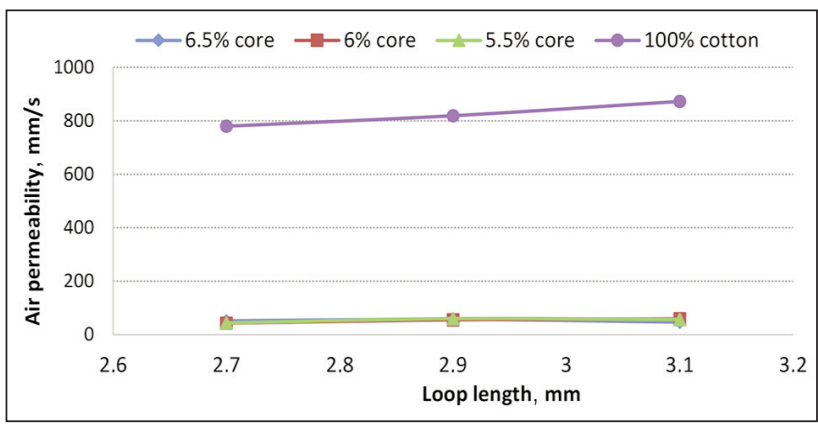

Fig. 8. Effect of loop length on the air permeability

\section{Spirality angle}

Spirality is the most common fabric defect that affects the single jersey knit wear fabric and it is the angle $(\theta)$ between the wale line and a line perpendicular to the course line [18] as shown in figure 9 . So, the spirality angle depends on the wales spacing and using of cotton/spandex core sun yarn in SJKF decreases

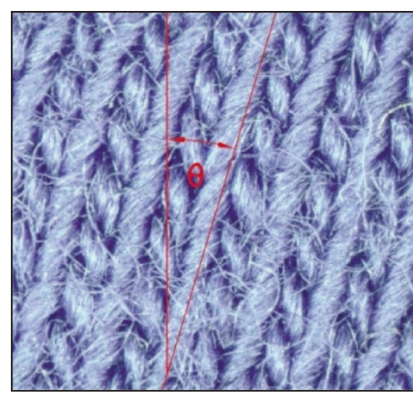

Fig. 9. Spirality angle $(\theta)$ 


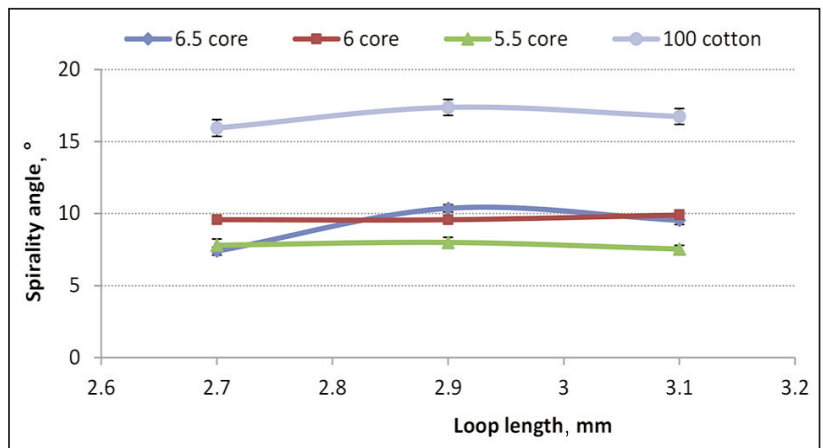

Fig. 10. Effect of loop length on the spirality angle

Table 3

THE RESULTS OF VARIANCE ANALYSIS (P VALUE AT CONFIDENCE INTERVAL 95\%)

\begin{tabular}{|l|c|c|}
\hline \multicolumn{1}{|c|}{$\begin{array}{c}\text { Dependent } \\
\text { property }\end{array}$} & $\begin{array}{c}\text { P value, } \\
\text { Independent } \\
\text { variable (spandex } \\
\text { percent) }\end{array}$ & $\begin{array}{c}\text { P value, } \\
\text { Independent } \\
\text { variable } \\
\text { (loop length) }\end{array}$ \\
\hline Thermal conductivity & 0.000 & 0.003 \\
\hline Thermal absorptivity & 0.000 & 0.313 \\
\hline Thermal resistance & 0.261 & 0.805 \\
\hline Air permeability & 0.705 & 0.000 \\
\hline $\begin{array}{l}\text { Water vapour } \\
\text { permeability }\end{array}$ & 0.009 & 0.528 \\
\hline Fabric thickness & 0.025 & 0.616 \\
\hline Spirality angle & 0.000 & 0.000 \\
\hline
\end{tabular}

the wales spacing and then decreases the spirality angle. Therefore, the spirality angle of elastic knitted fabrics are higher than $100 \%$ cotton fabric as shown in figure 10 .
The statistical analysis of the experimental results by variance analysis using SPSS software are listed in table 3 .

\section{CONCLUSIONS}

The dimensional and thermal comfort properties of cotton/spandex plain knitted fabric are investigated and compared to the properties of $100 \%$ cotton without spandex. The experimental results proposed that: - The thickness, stitch density, and density of elastic knitted fabric are higher than $100 \%$ cotton fabric.

- The thermal conductivity and resistance of cotton/ spandex samples increased by 17 and $47 \%$ respectively compared to $100 \%$ cotton fabric. So, the elastic fabric has ability to maintain the body temperature and it will be perfect in winter clothing.

- The thermal absorptivity of elastic fabric is more than $100 \%$ cotton by $29 \%$ and $53 \%$ at the loop length 2.7 and $3.1 \mathrm{~mm}$ respectively, which could give a cool feeling at first touch.

- The RWVP of elastic fabric is less than $100 \%$ cotton fabric that might give a discomfort feeling because it failed to transfer the water vapour out of the body to the fabric surface.

- The air permeability of elastic knitted fabric decreased by $94 \%$ and the spirality angle decreased $49 \%$ compared to $100 \%$ cotton fabric.

So, the use of spandex has two different effects, it enhances the dimensional stability, but also affects other important properties such as the RWVP, thermal absorptivity, and air permeability.

\section{ACKNOWLEDGEMENTS}

This work is supported under Student Grant Scheme (SGS 21316) by Technical University of Liberec, Czech Republic.

\section{REFERENCES}

[1] Sadek, R., El-Hossini, A.M., Eldeeb, A.S., Yassen, A.A., Effect of lycra extension percent on single jersey knitted fabric properties. In: Journal of Engineered Fibers and Fabrics, 2012, 7, 2, 155892501200700203

[2] Matusiak, M., Thermal comfort index as a method of assessing the thermal comfort of textile materials. In: Fibres \& Textiles in Eastern Europe, 2010, 18, 2, 79

[3] Boughattas, A., Benltoufa, S., Hes, L., Azeem, M., Fayala, F., Thermo-physiological properties of woven structures in wet state. In: Industria Textila, 2018, 69, 4, 298-303, http://doi.org/10.35530/IT.069.04.1452

[4] Unal, P.G., Ureyen, M.E., Mechanical and permeability properties of sportech fabrics, In: Industria Textila, 2016, 67, 3, 151-156

[5] Aboalasaad, A.R., Skenderi, Z., Brigita, K.S., Khalil, A.A., Analysis of Factors Affecting Thermal Comfort Properties of Woven Compression Bandages, In: Autex Research Journal, 2019, 1, http://doi.org/10.2478/aut-2019-0028

[6] Marmarali, A.B., Dimensional and physical properties of cotton/spandex single jersey fabrics, In: Textile Research Journal, 2003, 73, 1, 11-14

[7] Kizildag, N., Ucar, N., Gorgun, B., Analysis of some comfort and structural properties of cotton/spandex plain and $1 \times 1$ rib knitted fabrics. In: The Journal of the Textile Institute, 2016, 107, 5, 606-613

[8] Abdessalem, S.B., Abdelkader, Y.B., Mokhtar, S., Elmarzougui, S., Influence of elastane consumption on plated plain knitted fabric characteristics, In: Journal of Engineered Fibers and Fabrics, 2009, 4, 4, 155892500900400411

[9] Değirmenci, Z., Coruh, E., Comparison of the performance and physical properties of plain, pique, double-pique and fleeced knitted fabrics, In: Tekstil ve Konfeksiyon, 2016, 26, 2, 159-165

[10] Azim, A.Y.M.A., Sowrov, K., Ahmed, M., Hasan, H.R.U., Al Faruque, M.A., Effect of Elastane on Single Jersey Knit Fabric Properties-Physical \& Dimensional Properties. In: International Journal of Textile Science, 2014, 3, 1, 12-16 
[11] Kundu, S.K., Chowdhary, U., Effect of Fiber Content on Comfort Properties of Cotton/Spandex, Rayon/Spandex, and Polyester/Spandex Single Jersey Knitted Fabrics. In: International Journal of Polymer Textile Engineering, 2019, 5, 3, 33-39

[12] Tezel, S., Kavuşturan, Y., Experimental investigation of effects of spandex brand and tightness factor on dimensional and physical properties of cotton/spandex single jersey fabrics.In: Textile Research Journal, 2008, 78, 11, 966-976

[13] Eltahan, E., Effect of Lycra Percentages and Loop Length on the Physical and Mechanical Properties of Single Jersey Knitted Fabrics, In: Journal of Composites, 2016

[14] Herath, C.N., Kang, B.C., Jeon, H.Y., Dimensional stability of cotton-spandex interlock structures under relaxation, In: Fibers and polymers, 2007, 8, 1, 105

[15] Prakash, C., Thangamani, K., Establishing the effect of loop length on dimensional stability of single jersey knitted fabric made from cotton/lycra core spun yarn, In: Indian Journal of Science and Technology, 2010, 3, 287-289

[16] Senthilkumar, M., Anbumani, N., de Araujo, M., Elastic Properties of Spandex Plated Cotton Knitted Fabric, In: The Institution of Engineers (India), 2011, 92, 8, 9-13

[17] Fouda, A., Eldeeb, A.S., Properties of Weft Knitted Fabrics Made from Dual Core-Spun Yarns, In: $8^{\text {th }}$ International İstanbul Textile Conference - Evolution Technical Textile (ETT2018), April 14-16, 2018, İstanbul, Turkey, 2018, 1-7

[18] Lau, M., Tao, M., Torque-balanced Singles Knitting Yarns Spun by Unconventional Systems Part 11: Cotton Friction Spun DREF 111 Yarn, In: Textile Research Journal, 1997, 67, 11, 815-825

[19] Salama, A.A., El-Deeb, A.S., El-shahat, I.M., Evaluation of Bed Cover Properties Produced from Double Fabric Based on Honeycomb. In: Journal of Textiles, 2015

[20] Hes, L., Non-destructive determination of comfort parameters during marketing of functional garments and clothing, In: Indian Journal of Fibre and Textile Research, 2008, 33, 239-245

[21] Hes, L., Catalogues of the ALAMBETA and PERMETEST Instruments, SENSORA Co. (Czech Republic)

[22] Hes, L., De Araujo, M., Djulay, V.V., Effect of mutual bonding of textile layers on thermal insulation and thermal contact properties of fabric assemblies, In: Textile Research Journal, 1996, 66, 4, 245-250

[23] Afzal, A., Ahmad, S., Rasheed, A., Ahmad, F., Iftikhar, F., Nawab, Y., Influence of fabric parameters on thermal comfort performance of double layer knitted interlock fabrics, In: Autex Research Journal, 2017, 17, 1, 20-26

\author{
Authors: \\ AMANY KHALIL ${ }^{1,2}$, PAVLA TĚŠINOVÁ ${ }^{1}$, ABDELHAMID R.R. ABOALASAAD ${ }^{2,3}$ \\ ${ }^{1}$ Textile Evaluation Department, Technical University of Liberec 46117, Liberec, Czech Republic \\ ${ }^{2}$ Textile Engineering Department, Mansoura University, Mansoura 35516, Egypt \\ ${ }^{3}$ Technologies and Structures Dept., Technical University of Liberec, Liberec 46117, Czech Republic

\section{Corresponding author:} \\ AMANY KHALIL \\ e-mail: engamanysalama@gmail.com, Amany.khalil@tul.cz
}

